\title{
KEANEKARAGAMAN JENIS JAMUR MAKROSKOPIS PADA BERBAGAI KONDISI TEMPAT TUMBUH HUTAN RAWA GAMBUT DI KAWASAN HUTAN DENGAN TUJUAN KHUSUS UNIVERSITAS TANJUNGPURA
}

\author{
(Diversity of macroscopic fungi in various conditions the peat swamp forest in Tanjungpura \\ University Forest for Special Purpose)
}

\author{
Syapriadi Utama, Dwi Astiani, Wiwik Ekyastuti \\ Fakultas Kehutanan Universitas Tanjungpura Jl. Daya Nasional, Pontianak 78124 \\ Email: syapriadiutama@student.untan.ac.id
}

\begin{abstract}
Tanjungpura University Forest for Special Purpose located in three districts Landak Regency, Mempawah Regency and Kubu Raya Regency. Has the potential to use and process non-timber forest products. The diversity of macroscopic fungi is not yet known as one of the potential natural biological resources of significant value. So that a mushroom inventory must be carried out to identify and assess the diversity of macroscopic fungi. The method used is the survey method. Data retrieval uses a double plot sampling technique. The size of each observation plot is $5 \mathrm{~m} \times$ $5 \mathrm{~m}$ as the initial reference, four plots in the peat swamp forest area with open canopy cover conditions and also four observation plots in peat swamp forest areas with canopy cover conditions are still closed. Placement of research plots in both areas was carried out purposively in locations where there were many types of macroscopic fungi. The results showed that the types of macroscopic fungi found at the study site were 24 species. 24 species were divided into 594 individuals belonging to 23 genera and 9 families. Macroscopic fungi found in open canopy cover were found in 17 species, while in closed canopy cover there were 13 species. In both types of conditions the place to grow has the same 6 types of fungi. The degree of diversity of macroscopic fungi in various conditions the peat swamp in Tanjungpura University Forest for Special Purpose is low.
\end{abstract}

Keyword: Macroscopic fungi, peat swamp forest, Tanjungpura University Forest for Special Purpose.

\section{PENDAHULUAN}

Kawasan Hutan dengan Tujuan Khusus (KHDTK) berdasarkan Undang undang Republik Indonesia Nomor 41 Tahun 1999 pasal 8 adalah suatu kawasan hutan yang ditetapkan oleh pemerintah untuk kepentingan umum seperti penelitian dan pengembangan, pendidikan dan latihan serta religi dan budaya tanpa mengubah fungsi pokok kawasan hutan sebagai fungsi konservasi, lindung dan produksi. Melalui SK 656 /Menlhk/Setjen/PLA.0/8/2016 Tanggal 26 Agustus 2016, Kementerian
Lingkungan Hidup dan Kehutanan menetapkan KHDTK Universitas Tanjungpura, luas 19.662 Ha yang terletak di tiga kabupaten yaitu Kabupaten Landak, Kabupaten Mempawah dan Kabupaten Kubu Raya. Menurut Dewantara (2017), potensi - potensi KHDTK Universitas Tanjungpura yaitu memiliki sumber plasma nutfah untuk jenis-jenis vegetasi tipe hutan hujan tropis (riparian, hutan rawa, hutan gambut, hutan kerangas, hutan dataran rendah dan sedang) dan perlindungan keanekaragaman hayati. 
Pengembangan kepariwisataan alam, pendidikan lingkungan, dan manfaat sosial ekonomi lainnya.

Beberapa potensi yang khas antara lain kondisi tutupan hutan dan atau vegetasi sebagai cadangan karbon yang diharapkan dapat berkontribusi dalam program pengurangan tingkat emisi karbon di udara (penyerapan dan/atau penyimpanan karbon). Pemanfaatan dan pengolahan hasil hutan nir kayu (madu, tengkawang, rotan, getah, buah, jamur, gaharu, bambu, sarang burung walet). Sebagai sumber bahan baku obat-obatan (tanaman obat), tanaman hias, budidaya jamur, budidaya lebah, penangkaran satwa liar (aves, mamalia, reptil, herpetofauna) atau budidaya hijauan makanan ternak. Sebagai areal budidaya agroforestri dan sebagai kawasan pelestarian gambut dan tembawang (Dewantara, 2017).

Menunjang tujuan penetapan KHDTK sebagai suatu kawasan yang ditetapkan untuk melakukan riset, pengembangan ilmu pengetahuan dan konservasi potensi jamur makroskopis di KHDTK Universitas Tanjungpura dinilai penting untuk dilakukan penelitian. Jamur merupakan salah satu keunikan yang memperkaya keanekaragaman jenis mahkluk hidup. Beberapa jenis jamur telah banyak dimanfaatkan oleh manusia sebagai bahan makanan dan sumber bahan obat-obatan tradisional maupun modern (Parjimo dan Andoko, 2007). Faktor - faktor yang mempengaruhi keberadaan jamur makroskopis antara lain adalah faktor lingkungan yaitu kondisi tempat tumbuh, sehingga perlu diperoleh informasi tentang kondisi tempat tumbuh jamur tersebut untuk kelestarian dan pengembangan dimasa yang akan datang.

Keanekaragaman jenis jamur makroskopis di KHDTK Universitas Tanjungpura belum diketahui. Padahal jamur makroskopis adalah sebagai salah satu potensi sumber daya alam hayati yang bernilai penting. Oleh karena itu harus dilakukan inventarisasi jamur untuk mengidentifikasi dan menilai keanekaragaman jenis jamur makroskopis. Penelitian tentang keanekaragaman jenis pada berbagai kondisi tempat tumbuh jamur makroskopis ini akan dilakukan di kawasan hutan rawa gambut Kecamatan Mandor, Kabupaten Landak di KHDTK Universitas Tanjungpura.

\section{METODE PENELITIAN}

Penelitian dilakukan pada bulan April 2019 di kawasan hutan rawa gambut KHDTK Universitas Tanjungpura Kecamatan Mandor Kabupaten Landak. Penelitian dilaksanakan dengan metode survey. Pengambilan data dengan menggunakan teknik sampling petak ganda. Ukuran setiap petak pengamatan yaitu $5 \mathrm{~m} \times 5 \mathrm{~m}$ sebagai acuan awal, sebanyak empat petak pada kawasan hutan rawa gambut dengan kondisi tutupan tajuk terbuka dan juga empat petak pengamatan pada kawasan hutan rawa gambut dengan kondisi tutupan tajuk masih tertutup, sehingga secara keseluruhan dibuat 8 petak. Peletakan petak penelitian pada kedua kawasan tersebut dilakukan secara purposive pada lokasi yang banyak terdapat jenis - jenis jamur makroskopis. Pengambilan data dilakukan dengan cara membuat deskripsi singkat mengenai spesies dan habitat ditemukannya. Spesies 
yang ditemukan difoto dan diambil sebagai sempel untuk memudahkan dalam proses identifikasi.

Data utama yang diambil antara lain: jenis dan jumlah masing - masing jenis jamur makroskopis, kondisi tempat tumbuh (intensitas cahaya, suhu udara, suhu tanah, kelembaban udara, kelembaban tanah, tempat tumbuh dan vegetasi penutup tempat tumbuh). Data penunjang yang diperlukan meliputi: data iklim, keadaan umum lokasi penelitian dan data penunjang lainnya. Analisis data yang digunakan dalam penelitian ini adalah Indeks Nilai Penting (INP), Indeks dominansi (C), Indeks keanekaragaman jenis (H'), Indeks kemerataan jenis (e), Indeks kekayaan jenis (d), Indeks kesamaan jenis (IS).

\section{HASIL DAN PEMBAHASAN}

Komposisi Jenis Jamur Makroskopis

Pada Kondisi Tempat Tumbuh Hutan

Rawa Gambut di KHDTK Universitas

\section{Tanjungpura}

Jumlah petak pengamatan jamur makroskopis di hutan rawa gambut terbuka adalah 4 petak (petak 1-4) dan di hutan rawa gambut tertutup adalah 4 petak (petak 5-8). Jumlah jenis jamur makroskopis pada kondisi tempat tumbuh hutan rawa gambut sebanyak 24 spesies dengan 594 individu yang tergolong kedalam 23 genus dan 9 famili. Komposisi jamur makroskopis pada setiap petak penelitian disajikan pada Tabel. 1.

Tabel.1. Jenis - Jenis Jamur Makroskopis yang Ditemukan pada Setiap Petak Penelitian (Types of Macroscopic Fungi Found in Each Study Plot)

\begin{tabular}{|c|c|c|c|c|c|c|c|c|c|}
\hline \multirow{3}{*}{ No } & \multirow{3}{*}{ Nama Jenis } & \multicolumn{8}{|c|}{ Jumlah Individu } \\
\hline & & \multicolumn{4}{|c|}{ Gambut Terbuka } & \multicolumn{4}{|c|}{ Gambut Tertutup } \\
\hline & & 1 & 2 & 3 & 4 & 5 & 6 & 7 & 8 \\
\hline 1 & Agaricus $\mathrm{sp}$ & 0 & 1 & 0 & 0 & 0 & 0 & 0 & 0 \\
\hline 2 & Bjerkandera sp & 0 & 44 & 0 & 0 & 0 & 0 & 0 & 0 \\
\hline 3 & Coltricia $\mathrm{sp}$ & 9 & 0 & 6 & 0 & 53 & 29 & 0 & 0 \\
\hline 4 & Cropidotus $\mathrm{sp}$ & 11 & 0 & 9 & 0 & 0 & 0 & 0 & 18 \\
\hline 5 & Chantarellus sp & 16 & 0 & 0 & 0 & 0 & 0 & 0 & 0 \\
\hline 6 & Craterellus sp & 0 & 0 & 0 & 23 & 0 & 0 & 0 & 0 \\
\hline 7 & Daedalea $\mathrm{sp}$ & 0 & 0 & 7 & 0 & 9 & 0 & 0 & 0 \\
\hline 8 & Entolama $\mathrm{sp}$ & 0 & 0 & 0 & 0 & 2 & 0 & 0 & 0 \\
\hline 9 & Fomes sp & 4 & 0 & 0 & 4 & 0 & 0 & 44 & 0 \\
\hline 10 & Gleophillum sp & 0 & 0 & 0 & 5 & 0 & 0 & 0 & 0 \\
\hline 11 & Ganoderma sp1 & 0 & 0 & 0 & 0 & 4 & 0 & 0 & 0 \\
\hline 12 & Ganoderma sp2 & 0 & 0 & 0 & 0 & 0 & 0 & 0 & 34 \\
\hline 13 & Hapalopilus sp & 0 & 0 & 0 & 0 & 0 & 0 & 10 & 0 \\
\hline 14 & Hymenochaeta $\mathrm{sp}$ & 63 & 0 & 0 & 0 & 0 & 0 & 0 & 0 \\
\hline 15 & Inonotus $\mathrm{sp}$ & 0 & 0 & 0 & 0 & 0 & 0 & 0 & 7 \\
\hline 16 & Marasmiellus sp & 13 & 0 & 0 & 0 & 0 & 0 & 0 & 0 \\
\hline 17 & Meripilus sp & 0 & 0 & 1 & 0 & 0 & 0 & 0 & 0 \\
\hline 18 & Marasmius sp & 0 & 0 & 0 & 0 & 0 & 1 & 0 & 0 \\
\hline 19 & Omphalina sp & 2 & 68 & 3 & 0 & 0 & 0 & 0 & 0 \\
\hline 20 & Phellinus sp & 0 & 0 & 10 & 0 & 52 & 0 & 0 & 0 \\
\hline 21 & Polyporus sp & 2 & 0 & 0 & 0 & 0 & 7 & 8 & 0 \\
\hline 22 & Tyromyces sp & 0 & 0 & 7 & 0 & 0 & 0 & 0 & 0 \\
\hline 23 & Trametes $\mathrm{sp}$ & 0 & 0 & 0 & 5 & 0 & 0 & 0 & 0 \\
\hline \multirow[t]{2}{*}{24} & Trichaptum sp & 0 & 0 & 0 & 0 & 0 & 3 & 0 & 0 \\
\hline & Jumlah Total & 120 & 113 & 43 & 37 & 120 & 40 & 62 & 59 \\
\hline
\end{tabular}


Tabel 2. Jenis - Jenis Jamur Makroskopis, Klasifikasi dan Deskripsinya (Types, Classifications and Descriptions of Macroscopic Fungi)

\begin{tabular}{|c|c|c|}
\hline Jenis Jamur & $\begin{array}{c}\text { Klasifikasi } \\
\text { Thomas Laessoe \& } \\
\text { Gary Lincoof }\end{array}$ & Deskripsi \\
\hline 1 & 2 & 3 \\
\hline & $\begin{array}{l}\text { Famili : } \\
\text { Agaricaceae } \\
\text { Genus: } \\
\text { Agaricus }\end{array}$ & $\begin{array}{l}\text { Bentuk tudung lingkaran dengan } \\
\text { sisik berwarna orange-coklat } \\
\text { pada permukaan tutup dan } \\
\text { batang. Berbau almond } \\
\text { mengidentifikasi jenis ini. } \\
\text { Memiliki cincin dibawah tudung. } \\
\text { Ditemukan pada pohon mati dan } \\
\text { disemua jenis kayu serta tanaman } \\
\text { di tanah yang subur dan kompos. } \\
\text { dagingnya yang keras dan } \\
\text { melimpah ia menjadi pilihan } \\
\text { yang dapat dimakan. }\end{array}$ \\
\hline & $\begin{array}{l}\text { Famili : } \\
\text { Polyporaceae } \\
\text { Genus: Bjerkandera }\end{array}$ & $\begin{array}{l}\text { Bentuk tudung } 1 / 4 \text { lingkaran } \\
\text { dengan zona konsentris abu-abu } \\
\text { coklat, permukaan berombak } \\
\text { yang bergelombang dan margin } \\
\text { melengkung. Baunya sangat } \\
\text { menjamur. Jenis ini ditemukan } \\
\text { tumbuh pada pohon mati, bersifat } \\
\text { parasit atau saptrotofik pada } \\
\text { pohon. }\end{array}$ \\
\hline al & $\begin{array}{l}\text { Famili : } \\
\text { Hymenochaetaceae } \\
\text { Genus: } \\
\text { Coltricia }\end{array}$ & $\begin{array}{l}\text { Bentuk tudung } 1 / 2 \text { lingkaran } \\
\text { berwarna coklat keemasan } \\
\text { Permukaan atas mengkilap } \\
\text { memiliki zona konsentris dalam } \\
\text { nuansa cokelat keemasan. Bagian } \\
\text { bawah memiliki insang coklat } \\
\text { keabu - abuan, tidak memiliki } \\
\text { cincin dan cawan pada batang. }\end{array}$ \\
\hline Cropidotus sp & $\begin{array}{l}\text { Famili : } \\
\text { Crepidotaceae } \\
\text { Genus: } \\
\text { Cropidotus }\end{array}$ & $\begin{array}{l}\text { Bentuk tudung } 1 / 2 \text { lingkaran } \\
\text { berwarna putih dengan } \\
\text { permukaan tutup kering dan } \\
\text { memiliki serat halus abu - abu } \\
\text { berlingkaran konsentris. } \\
\text { Tutupnya sering menempel pada } \\
\text { substrat di bagian belakangnya. } \\
\text { Jenis ini ditemukan hidup pada } \\
\text { pohon mati tanaman busuk dan } \\
\text { daun busuk. }\end{array}$ \\
\hline
\end{tabular}




\begin{tabular}{|c|c|c|}
\hline Cho & $\begin{array}{l}\text { Famili : } \\
\text { Chantarellaceae } \\
\text { Genus: } \\
\text { Chantarellus }\end{array}$ & $\begin{array}{l}\text { Bentuk tudung lingkaran corong } \\
\text { berwarna sangat cerah dengan } \\
\text { margin bergelombang. Daging } \\
\text { berserat yang dapat dimakan } \\
\text { cukup tipis dan berwarna merah } \\
\text { hingga putih pucat pada } \\
\text { tutupnya. Lebih tebal dan puth } \\
\text { pada batangnya Jenis ini } \\
\text { ditemukan pada pohon mati. }\end{array}$ \\
\hline & $\begin{array}{l}\text { Famili : } \\
\text { Chantarellaceae } \\
\text { Genus: } \\
\text { Craterellus }\end{array}$ & $\begin{array}{l}\text { Tudung berbentuk terompet } \\
\text { berwarna coklat berongga dan } \\
\text { meruncing ke arah alas. Daging } \\
\text { abu - abu tipis terasa ringan dan } \\
\text { menyenangkan dengan aroma } \\
\text { aromatik. Tidak memiliki cincin } \\
\text { dan cawan. }\end{array}$ \\
\hline & $\begin{array}{l}\text { Famili : } \\
\text { Polyporaceae } \\
\text { Genus: } \\
\text { Daedalea }\end{array}$ & $\begin{array}{l}\text { Bentuk tudung } 1 / 2 \text { lingkaran } \\
\text { berwarna krem atau oker abu - } \\
\text { abu pucat dengan permukaan } \\
\text { halus tapi tidak rata dan berkerut. } \\
\text { Bau samar - samar menjamur. }\end{array}$ \\
\hline & $\begin{array}{l}\text { Famili : } \\
\text { Entolomataceae } \\
\text { Genus: } \\
\text { Entolama }\end{array}$ & $\begin{array}{l}\text { Bentuk tudung lingkaran } \\
\text { berwarna madu-kecoklatan } \\
\text { dengan garis yang jelas pada } \\
\text { tudung dan tinggi tubuhnya. Jenis } \\
\text { ini ditemukan tumbuh pada } \\
\text { serasah di bawah tumbuhan } \\
\text { rimbun di tanah yang kaya humus } \\
\text { dan bersifat asam. }\end{array}$ \\
\hline Fomes sp & $\begin{array}{l}\text { Famili : } \\
\text { Polyporaceae } \\
\text { Genus: } \\
\text { Fomes }\end{array}$ & $\begin{array}{l}\text { Bentuk tudung } 1 / 2 \text { lingkaran } \\
\text { berkuku dengan zona bervariasi } \\
\text { dari coklat tua di daerah yang } \\
\text { lebih tua hingga coklat pucat } \\
\text { pada margin yang tumbuh. Jenis } \\
\text { ini ditemukan tumbuh pada } \\
\text { pohon mati dan bersifat parasit } \\
\text { pada pohon dan tidak memiliki } \\
\text { tangkai. Memiliki aroma asam } \\
\text { yang khas. }\end{array}$ \\
\hline
\end{tabular}




\begin{tabular}{|c|c|c|}
\hline Gleophillum s & $\begin{array}{l}\text { Famili : } \\
\text { Polyporaceae } \\
\text { Genus: } \\
\text { Gleophillum }\end{array}$ & $\begin{array}{l}\text { Tudung berbentuk bantal dan } \\
\text { sedikit terasa, marginnya kuning } \\
\text { keemasan ke orange bagian yang } \\
\text { lebih tua hampir berwarna hitam. } \\
\text { Daging seperti gabus berwarna } \\
\text { coklat karat. Jenis ini ditemukan } \\
\text { pada pohon mati dan tidak } \\
\text { memiliki tangkai. }\end{array}$ \\
\hline Gane & $\begin{array}{l}\text { Famili : } \\
\text { Ganodermataceae } \\
\text { Genus: } \\
\text { Ganoderma }\end{array}$ & $\begin{array}{l}\text { Bentuk tudung } 1 / 2 \text { lingkaran } \\
\text { berwarna coklat dengan } \\
\text { permukaan tidak rata, pinggiran } \\
\text { konsentris dan margin tipis. } \\
\text { Sering dengan kantong jaring } \\
\text { putih, memiliki rasa pahit dan } \\
\text { bau jamur. Jenis ini ditemukan } \\
\text { pada pohon mati dan tidak } \\
\text { memiliki tangkai. }\end{array}$ \\
\hline & $\begin{array}{l}\text { Famili : } \\
\text { Ganodermataceae } \\
\text { Genus: } \\
\text { Ganoderma }\end{array}$ & $\begin{array}{l}\text { Bentuk tudung tiram, berwarna } \\
\text { merah mengkilap dan ungu- } \\
\text { hitam dengan tepian konsentris, } \\
\text { pinggir yang lebih pucat dan } \\
\text { batang coklat yang dipernis di } \\
\text { satu sisi. Jenis ini ditemukan } \\
\text { tumbuh pada pohon mati dan } \\
\text { tidak memiliki tangkai berdaging } \\
\text { keras. }\end{array}$ \\
\hline & $\begin{array}{l}\text { Famili : } \\
\text { Polyporaceae } \\
\text { Genus: Hapalopilus }\end{array}$ & $\begin{array}{l}\text { Bentuk tudung } 1 / 2 \text { lingkaran atau } \\
\text { kipas berwarna kayu kemerah } \\
\text { permukaan, daging dan lapisan } \\
\text { tabung. Daging yang bertekstur } \\
\text { lembut tidak bisa dimakan. Jenis } \\
\text { ini ditemukan tumbuh pada } \\
\text { pohon mati dan tidak memiliki } \\
\text { tangkai. }\end{array}$ \\
\hline & $\begin{array}{l}\text { Famili : } \\
\text { Hymenochaetaceae } \\
\text { Genus: } \\
\text { Hymenochaeta }\end{array}$ & $\begin{array}{l}\text { Bentuk tudung } 1 / 2 \text { lingkaran } \\
\text { berwarna hitam kecoklatan } \\
\text { dengan tepi bergelombang. } \\
\text { Permukaan atas ditandai dengan } \\
\text { zona coklat konsentris, } \\
\text { bertambah jumlahnya dan } \\
\text { bertambah gelap seiring } \\
\text { bertambahnya usia. Bagian } \\
\text { bawah coklat dan tampak halus. }\end{array}$ \\
\hline
\end{tabular}




\begin{tabular}{|c|c|c|}
\hline & $\begin{array}{l}\text { Famili : } \\
\text { Hymenochaetaceae } \\
\text { Genus: } \\
\text { Inonotus }\end{array}$ & $\begin{array}{l}\text { Memiliki bentuk tudung } 1 / 2 \\
\text { lingkaran atau kipas berdaging } \\
\text { tebal spesies ini dibedakan oleh } \\
\text { permukaan yang kasar. } \\
\text { Berwarna merah menyalaketika } \\
\text { muda secara bertahap berubah } \\
\text { menjadi coklat dari bagian } \\
\text { dalam tubuh buah ke arah luar: } \\
\text { permukaan pori berwarna coklat } \\
\text { pucat putih. Menjadi lebih gelap } \\
\text { dengan bertambah usia dan } \\
\text { sering tampak mengkilap. }\end{array}$ \\
\hline & $\begin{array}{l}\text { Famili : } \\
\text { Tricholomataceae } \\
\text { Genus: } \\
\text { Marasmiellus }\end{array}$ & $\begin{array}{l}\text { Memiliki bentuk tudung } \\
\text { lingkaran berwarna putih yang } \\
\text { cembung, menua rata dan } \\
\text { berkerut. Tangkai putih pendek } \\
\text { melengkung, mirip dengan warna } \\
\text { tagkai dagingnya putih pucat dan } \\
\text { berserat. }\end{array}$ \\
\hline Meripilus sp & $\begin{array}{l}\text { Famili : } \\
\text { Riqidoporaceae } \\
\text { Genus: } \\
\text { Meripilus }\end{array}$ & $\begin{array}{l}\text { Spesies ini menghasilkan tanda } \\
\text { kurung tahunan yang padat dari } \\
\text { satu batang. Setiap tudung } \\
\text { berbentuk kipas memiliki } \\
\text { permukaan yang halus dengan } \\
\text { zona cokelat keemasan } \\
\text { konsentris dan margin } \\
\text { bergelombang. Daging puth } \\
\text { yang menyenangkan berbau } \\
\text { lembut dan berserat. }\end{array}$ \\
\hline & $\begin{array}{l}\text { Famili : } \\
\text { Tricolomataceae } \\
\text { Genus: } \\
\text { Marasmius }\end{array}$ & $\begin{array}{l}\text { Bentuk tudung } 3 / 4 \text { lingkaran } \\
\text { berwarna putih dengan bagian } \\
\text { bawah tudung berbentuk roda } \\
\text { atau kerah pada bagian atas } \\
\text { batang. Tudung berbentuk } \\
\text { cembung memiliki bagian pusat } \\
\text { yang lebih gelap seperti pusar } \\
\text { dalam alur radial. }\end{array}$ \\
\hline
\end{tabular}




\begin{tabular}{|c|c|c|}
\hline & $\begin{array}{l}\text { Famili : } \\
\text { Tricholomataceae } \\
\text { Genus: } \\
\text { Omphalina }\end{array}$ & $\begin{array}{l}\text { Memiliki bentuk tudung } \\
\text { lingkaran seperti corong } \\
\text { berwarna putih dengan batang } \\
\text { tipisnya halus dan juga berwarna } \\
\text { putih. Dagingnya sangat tipis } \\
\text { berwarna putih pucat. Jenis ini } \\
\text { ditemukan tumbuh pada pohon } \\
\text { mati, dapat bertahan pada kondisi } \\
\text { lingkungan asam yang kuat. }\end{array}$ \\
\hline Phe & $\begin{array}{l}\text { Famili : } \\
\text { Hymenochaetaceae } \\
\text { Genus: } \\
\text { Phellinus }\end{array}$ & $\begin{array}{l}\text { Bentuk tudung } 1 / 2 \text { lingkaran atau } \\
\text { kuku berwarna abu-abu hampir } \\
\text { hitam dengan margin tebal. } \\
\text { Daging dan tudung yang keras } \\
\text { berwarna cokelat berkarat. Dapat } \\
\text { tumbuh pada pohon inang yang } \\
\text { hidup selama bertahun - tahun. } \\
\text { Jenis ini ditemukan tumbuh pada } \\
\text { pohon mati bersifat parasit pada } \\
\text { sejumlah pohon gugur. }\end{array}$ \\
\hline Polyporus & $\begin{array}{l}\text { Famili : } \\
\text { Polyporaceae } \\
\text { Genus: } \\
\text { Polyporus }\end{array}$ & $\begin{array}{l}\text { Memiliki bentuk tudung } 3 / 4 \\
\text { lingkaran berwarna hitam yang } \\
\text { halus dan mengkilap berwarna } \\
\text { abu - abu pucat ketika muda. } \\
\text { Tangkai pendek menempel di } \\
\text { tengah atau di pinggir, tidak } \\
\text { memiliki cincin dan cawan. Jenis } \\
\text { ini ditemukan tumbuh pada } \\
\text { pohon mati dengan kondisi hutan } \\
\text { yang lembab pada pohon yang } \\
\text { gugur. }\end{array}$ \\
\hline Tyromyces $\mathrm{sp}$ & $\begin{array}{l}\text { Famili : } \\
\text { Polyporaceae } \\
\text { Genus: } \\
\text { Tyromyces }\end{array}$ & $\begin{array}{l}\text { Bentuk tudung } 1 / 2 \text { lingkaran } \\
\text { sehingga membentuk ginjal } \\
\text { berwarna putih pucat dan hitam } \\
\text { coklelat konsentris bagian atas. } \\
\text { Penampang segitiga yang khas, } \\
\text { memiliki permukaan yang kasar, } \\
\text { berkutil dan daging putih lembut. } \\
\text { Dalam cuaca lembab insang } \\
\text { mengeluarkan cairan putih pudar } \\
\text { yang mengering menjadi putih } \\
\text { krem. Tidak memiliki tangkai } \\
\text { dan cincin. }\end{array}$ \\
\hline
\end{tabular}




\begin{tabular}{|c|l|l|}
\hline Trametes sp & $\begin{array}{l}\text { Famili : } \\
\text { Polyporaceae } \\
\text { Genus: } \\
\text { Trametes }\end{array}$ & $\begin{array}{l}\text { Bentuk tudung 1/2 lingkaran yang } \\
\text { tipis dan berlapis dengan zona } \\
\text { warna abu - abu atau cokelat } \\
\text { mencirikan jamur ini. Sempit } \\
\text { menempal pada substrat, tudung } \\
\text { banyak berbentuk kipas. Jenis ini } \\
\text { ditemukan tumbuh pada pohon } \\
\text { matidan tidak memiliki tangkai. }\end{array}$ \\
\hline Trichaptum $\mathrm{sp}$ & $\begin{array}{l}\text { Famili : } \\
\text { Polyporaceae } \\
\text { Genus: } \\
\text { Trichaptum }\end{array}$ & $\begin{array}{l}\text { Bentuk tudung 1/2 lingkaran atau } \\
\text { kipas dengan lekukan konsentris } \\
\text { berwarna cokelat margin } \\
\text { bergelombang dan melengkung. } \\
\text { Memiliki daging yang keras, } \\
\text { insang sudut terbelah seiring } \\
\text { bertambahnya usia. Jenis ini } \\
\text { ditemukan tumbuh pada pohon } \\
\text { mati dan tidak memiliki cawan } \\
\text { dan cincin pada tangkai. }\end{array}$ \\
\hline
\end{tabular}

Jamur makroskopis yang di temukan sebanyak 24 jenis tergolong jamur kayu karena tempat tumbuh semua jamur tersebut berada di pohon - pohon mati dan serasah. Hal ini sesuai dengan penelitian Hasanuddin (2014), yang menemukan bahwa jamur kayu adalah jamur yang menempel pada pohon kayu yang mengalami proses pelapukan, namun beberapa jenis jamur kayu ada yang tumbuh pada batang yang masih hidup, yaitu menempel pada lapisan luar batang. Peranan jamur kayu di hutan diantaranya adalah sebagai pengurai, bahan makanan, dan obat-obatan. Dari jenis jamur yang ditemukan ada empat jenis jamur yang dapat dimakan menurut Laessoen dan Lincoff (2002), yaitu Chantarellus sp, Agaricus sp, Meripilus sp dan Craterellus sp, sedangkan jenis Entolama sp tergolong jenis jamur yang berbahaya untuk dimakan atau dikonsumsi.
Tingkat Keanekaragaman Jenis Jamur Makroskopis pada Kondisi Tempat Tumbuh Hutan Rawa Gambut Tajuk Terbuka.

Tingkat keanekaragaman jenis jamur makroskopis di lokasi penelitian dapat diketahui dari hasil perhitungan Indeks Dominansi, Indeks Keanekaragaman, Indeks Kemerataan, dan Indeks Kekayaan Jenis. Luas seluruh petak pengambilan sampel pada kondisi tempat tumbuh tajuk terbuka seluas 0,0217 Ha. Jumlah jenis yang di temukan sebanyak 17 jenis dengan jumlah individu seluruh jenis sebanyak 313 individu. Tingkat keanekaragaman jenis jamur makroskopis pada kondisi tempat tumbuh tajuk terbuka dapat dilihat pada Tabel 3. 
Tabel 3. Indeks Dominansi, Indeks Keanekaragaman, Indeks Kemerataan, Indeks Kekayaan Jenis, Kerapatan dan Indeks Nilai Penting pada Kondisi Tempat Tumbuh Tajuk Terbuka (Dominance Index, Diversity Index, Evenness Index, Index Wealth Species, Density and Indices of Important Value at Site Conditions Grow Open Headings)

\begin{tabular}{|c|c|c|c|c|c|c|c|}
\hline NO & Nama Jenis & $\mathbf{C}$ & H & e & d & $\mathbf{K}$ & INP \\
\hline 1 & Agaricus $\mathrm{sp}$ & 0,00001 & 0,007 & & & 46,08 & 7,56 \\
\hline 2 & Bjerkandera $\mathrm{sp}$ & 0,01976 & 0,119 & & & 2027,64 & 21,3 \\
\hline 3 & Coltricia $\mathrm{sp}$ & 0,00229 & 0,063 & & & 691,24 & 24,77 \\
\hline 4 & Cropidotus sp & 0,00408 & 0,076 & & & 921,65 & 26,37 \\
\hline 5 & Chantarellus sp & 0,00261 & 0,066 & & & 737,32 & 14,46 \\
\hline 6 & Craterellus sp & 0,00539 & 0,083 & & & 1059,9 & 14,59 \\
\hline 7 & Daedalea $\mathrm{sp}$ & 0,0005 & 0,036 & & & 322,58 & 12,86 \\
\hline 8 & Fomes sp & 0,00065 & 0,04 & & & 368,66 & 19,15 \\
\hline 9 & Gleophillum $\mathrm{sp}$ & 0,00025 & 0,028 & & & 230,41 & 8,84 \\
\hline 10 & Hymenochaeta $\mathrm{sp}$ & 0,04051 & 0,14 & & & 2903,22 & 29,48 \\
\hline 11 & Marasmiellus sp & 0,00172 & 0,057 & & & 599,07 & 13,5 \\
\hline 12 & Meripilus sp & 0,00001 & 0,007 & & & 46,08 & 10,95 \\
\hline 13 & Omphalina sp & 0,05439 & 0,147 & & & 3364,05 & 50,55 \\
\hline 14 & Phellinus sp & 0,00102 & 0,047 & & & 460,82 & 13,82 \\
\hline 15 & Polyporus sp & 0,00004 & 0,014 & & & 92,16 & 9,99 \\
\hline 16 & Tyromyces sp & 0,0005 & 0,036 & & & 322,58 & 12,86 \\
\hline \multirow[t]{2}{*}{17} & Trametes sp & 0,00025 & 0,028 & & & 230,41 & 8,84 \\
\hline & Jumlah & 0,13 & 0,99 & $\mathbf{0 , 8 1}$ & 16,59 & & \\
\hline
\end{tabular}

Keterangan:

C : Indeks Dominansi

$\mathrm{H}$ : Indeks Keanekaragaman

e : Indeks Kemerataan

d : Indeks Kekayaan

$\mathrm{K}$ : Kerapatan

INP : Indeks Nilai Penting

Jenis jamur yang memiliki kelimpahan paling tinggi yaitu Omphalina sp dengan nilai INP sebesar 50,55 \%, jenis ini juga memiliki nilai kerapatan paling tinggi dari jenis-jenis lainnya. Menurut Priskila dkk. (2018) Hal ini berarti bahwa jenis-jenis yang ditemukan mempunyai kemampuan untuk beradaptasi dengan lokasi tersebut, serta pola penyebaran yang lebih baik dibandingkan dengan jenis jamur lainnya.

Kelimpahan jenis jamur yang ditemukan paling sedikit yaitu jamur jenis Agaricus sp dengan nilai INP sebesar 7,56 $\%$ dan tingkat kerapatan 46,08. Tingkat

keanekaragaman jenis jamur makroskopis pada kondisi tempat tumbuh tajuk terbuka tergolong kategori tingkat keanekaragaman jenis rendah karena memiliki nilai 0,994 lebih kecil dari nilai 1,5 yang menurut rumus indeks keanekaragaman jenis Shanon-Wiener. Tingkat kekayaan jenis jamur makroskopis tergolong tingkat kekayaan jenis tinggi karena memiliki nilai 16,59 lebih besar dari nilai 3,5 yang menurut rumus indeks kekayaan jenis Odum (1993). Nilai indeks kemerataan jenis jamur makroskopis didapatkan hasil sebesar 0,81 berarti bahwa komunitas 
jamur makroskopis pada kawasan penelitian tidak hanya didimonasi satu jenis.Kondisi lingkungan pada kawasan gambut tajuk terbuka kurang cocok untuk pertumbuhan jenis - jenis jamur yang tidak tahan terhadap kondisi panas. Suhu udara di lokasi penelitian di pagi hari sebesar 23 $24{ }^{\circ} \mathrm{C}$ sedangkan suhu udara di siang hari mencapai $32-33{ }^{\circ} \mathrm{C}$. Keasaman tanah disetiap petak berkisar diantara 3,4 - 3,5 adalah tergolong asam. Jenis jamur makroskopis ditemukan sedikit di lokasi penelitian. Menurut Hasanuddin (2014), jamur dapat tumbuh baik di daerah beriklim dingin maupun panas dengan suhu optimum antara $20-28{ }^{\circ} \mathrm{C}$, jamur akan tumbuh dan berkembang dengan baik pada suhu $16{ }^{\circ} \mathrm{C}$, kelembapan $97 \%$ serta $\mathrm{pH}$ optimum antara 5 - 7,5. Sedangkan pada kondisi tempat tumbuh hutan rawa gambut tutupan tajuk terbuka memiliki kelembaban tanah di pagi hari sebesar $80-90 \%$ dan di siang harinya hanya memiliki kelembaban sebesar $60-70 \%$, ini disebabkan keadaan lokasi yang memiliki suhu cukup panas dengan intensitas cahaya di pagi hari sebesar 91 - 95 Lux, dan di siang hari sebesar 1230 - 1280 Lux.

Tingkat Keanekaragaman Jenis Jamur Makroskopis pada Kondisi Tempat Tumbuh Hutan Rawa Gambut Tajuk Tertutup.

Luas seluruh petak pengambilan sampel pada kondisi tempat tumbuh tajuk tertutup adalah $0,015 \mathrm{Ha}$. Jumlah jenis yang di temukan sebanyak 13 jenis dengan jumlah individu seluruh jenis sebanyak 281 individu. Tingkat keanekaragaman jenis jamur makroskopis pada kondisi tempat tumbuh tajuk tertutup dapat dilihat pada Tabel 4.

Tabel 4. Indeks Dominansi, Indeks Keanekaragaman, Indeks Kemerataan, Indeks Kekayaan Jenis, Kerapatan dan Indeks Nilai Penting pada Kondisi Tempat Tumbuh Tajuk Tertutup (Dominance Index, Diversity Index, Evenness Index, Index Wealth Species, Density and Indices of Important Value at Site Conditions Grow Closed Headers)

\begin{tabular}{|c|c|c|c|c|c|c|c|}
\hline No & Nama Jenis & $\mathbf{C}$ & $\mathbf{H}$ & e & d & $\mathbf{K}$ & INP \\
\hline 1 & Coltricia $\mathrm{sp}$ & 0,08515 & 0,156 & & & 5466,66 & 53,89 \\
\hline 2 & Cropidotus sp & 0,0041 & 0,076 & & & 1200 & 17,73 \\
\hline 3 & Daedalea $\mathrm{sp}$ & 0,00102 & 0,047 & & & 600 & 14,53 \\
\hline 4 & Entolama $\mathrm{sp}$ & 0,00005 & 0,015 & & & 133,33 & 12,04 \\
\hline 5 & Fomes sp & 0,02451 & 0,126 & & & 2933,33 & 34,26 \\
\hline 6 & Ganoderma sp1 & 0,0002 & 0,026 & & & 266,66 & 12,75 \\
\hline 7 & Ganoderma sp2 & 0,01464 & 0,11 & & & 2266,66 & 23,43 \\
\hline 8 & Hapalopilus sp & 0,00126 & 0,051 & & & 666,66 & 22,16 \\
\hline 9 & Inonotus $\mathrm{sp}$ & 0,00062 & 0,039 & & & 466,66 & 13,82 \\
\hline 10 & Marasmius sp & 0,00001 & 0,008 & & & 66,66 & 13,73 \\
\hline 11 & Phellinus sp & 0,03424 & 0,135 & & & 3466,66 & 29,83 \\
\hline 12 & Polyporus sp & 0,00284 & 0,067 & & & 1000 & 37,32 \\
\hline \multirow[t]{2}{*}{13} & Trichaptum $\mathrm{sp}$ & 0,00011 & 0,021 & & & 200 & 14,45 \\
\hline & Jumlah & 0,16 & 0,87 & $\mathbf{0 , 7 9}$ & 12,59 & & \\
\hline
\end{tabular}

\footnotetext{
Keterangan:

C : Indeks Dominansi

$\mathrm{H}$ : Indeks Keanekaragaman

e : Indeks Kemerataan

d : Indeks Kekayaan

$\mathrm{K}$ : Kerapatan

INP : Indeks Nilai Penting
} 
Jenis jamur makroskopis yang paling banyak ditemukan di lokasi penelitian yaitu Coltricia sp dengan nilai INP sebesar 53,89 \%. Jenis ini mendapatkan nilai kerapatan adalah 5466,66. Jamur makroskopis yang paling sedikit adalah jenis Entolama sp dengan nilai INP sebesar 12,04\% dan kerapatan jenis sebesar 133,33. Tingkat keanekaragaman jenis jamur makroskopis pada kondisi tempat tumbuh tajuk tertutup tidak jauh berbeda dibandingkan dengan tingkat keanekaragaman jenis pada kondisi tempat tumbuh tajuk terbuka. Tingkat keanekaragaman jenis tergolong tingkat keanekaragaman jenis rendah degan nilai indeks keanekaragaman jenis sebesar 0,877. Tingkat kekayaan jenis jamur makroskopis tergolong tingkat kekayaan jenis tinggi dengan nilai indeks kekayaan jenis 12,59 yang menurut rumus indeks kekayaan jenis besar dari nilai 3,5 tergolong tingkat kekayaan jenis tinggi. Nilai indeks kemerataan jenis jamur makroskopis didapatkan hasil sebesar 0,79 berarti keberadaan jenis jamur makroskopis masih belum merata persebarannya.

Faktor lingkungan seperti suhu, kelembapan dan faktor biotik (penutupan tajuk), berpengaruh pada pertumbuhan jamur. Kondisi lingkungan pada hutan rawa gambut tajuk tertutup hampir sama dengan kondisi lingkungan tutupan tajuk terbuka yaitu suhu udara di pagi hari sebesar $22-24^{\circ} \mathrm{C}$ dan di siang hari mencapai $31-32{ }^{\circ} \mathrm{C}$, sedangkan suhu tanah pada lokasi penelitian ini di pagi hari sebesar $24-27^{\circ} \mathrm{C}$ dan di saat siang hari suhu tanah mencapai $29-31$ ${ }^{\circ} \mathrm{C}$. Kelembapan juga termasuk faktor yang mempengaruhi pertumbuhan jamur, di lokasi penelitian hutan rawa gambut tajuk tertutup memiliki kelembapan udara di pagi hari sebesar 97 - 98,5\% dan di siang hari mencapai kelembapan sebesar 73 - $75 \%$, sedangkan kelembapan tanah di pagi hari sebesar 95 - $99 \%$ dan di siang hari kelembapan tanah sebesar $73-75 \%$. Intensitas cahaya juga mempengaruhi untuk lingkungan hidup jamur, cahaya yang masuk ke lantai hutan dapat menyebabkan pertumbuhan jamur untuk spesies tertentu menjadi terhambat. Pada lokasi penelitian hutan rawa gambut tertutup memiliki intensitas cahaya di pagi hari sebesar 22 - 25 Lux dan di siang hari intensitas cahaya mencapai 280 - 290 Lux. Keasaman tanah pada lokasi penelitian mencapai nilai $\mathrm{pH}$ 3,5 3,6 atau memiliki keasaman yang cukup tinggi.

\section{Tingkat Kesamaan Jenis Jamur Makroskopis pada Kondisi Tempat Tumbuh Hutan Rawa Gambut Tajuk Terbuka dan Tajuk Tertutup di KHDTK Universitas Tanjungpura.}

Penelitian keanekaragaman jenis jamur makroskopis ini dilakukan pada dua tipe kondisi tempat tumbuh yaitu kawasan hutan rawa gambut tajuk terbuka dan kawasan hutan rawa gambut tajuk tertutup. Kedua tipe kawasan hutan tersebut sebagai perbandingan tingkat keanekaragaman dan kesamaan jenis jamur makroskopis di lokasi penelitian.

Tingkat kesamaan jenis jamur makroskopis pada kedua tipe tempat 
tumbuh yaitu hutan rawa gambut tajuk terbuka dan hutan rawa gambut tajuk tertutup tergolong tingkat kesamaan jenis sedang dengan nilai indeks kesamaan jenis sebesar $40 \%$. Jenis jenis jamur makroskopis yang sama ditemukan pada kedua tipe tempat tumbuh sebanyak enam jenis jamur yaitu Coltricia sp, Phellinus sp, Daedalea sp, Polyporus sp, Fomes sp dan Cropidotus sp. Dari kedua tipe tempat tumbuh jamur makroskopis pada kondisi tempat tumbuh hutan rawa gambut tajuk terbuka memiliki 11 jenis jamur yang berbeda di bandingkan dengan kondisi hutan rawa gambut tajuk tertutup. Sebaliknya pada kondisi tempat tumbuh hutan rawa gambut tajuk tertutup memiliki 7 jenis jamur makroskopis yang berbeda. Hal ini menunjukkan variasi jenis - jenis jamur makroskopis pada lokasi penelitian cukup bervariasi namun hasil analisis nilai indeks keanekaragaman adalah rendah.

Hasil penelitian ini menunjukkan hasil yang hampir sama dengan penelitian (Wahyudi dkk. 2012) yaitu inventarisasi jenis - jenis jamur makroskopis di hutan rawa gambut Desa Teluk Bakung, Kecamatan Sungai Ambawang, Kabupaten Kubu Raya. Hasil penelitian diperoleh 20 spesies jamur makroskopis terdiri dari 9 famili dan 15 genus dengan tingkat keanekaragaman jenis jamur tergolong rendah. Faktor abiotik yang mempengaruhi penyebaran dan pertumbuhan jamur dapat menjadi salah satu faktor yang menentukan rendahnya keanekaragaman jenis jamur dalam lokasi penelitian. Setiorini dkk, (2018) mengatakan selain itu kondisi tutupan tajuk yang berbeda dan cuaca yang akhir-akhir ini tidak stabil dapat saja mempengaruhi jumlah pertumbuhan jamur.

\section{KESIMPULAN}

1. Penelitian keanekaragaman jenis jamur makroskopis pada berbagai kondisi tempat tumbuh hutan rawa gambut di KHDTK Universitas Tanjungpura ditemukan sebanyak 24 spesies dengan 594 individu yang tergolong kedalam 23 genus dan 9 famili. Jamur makroskopis yang ditemukan pada kondisi tempat tumbuh tutupan tajuk terbuka ditemukan sebanyak 17 jenis sedangkan pada kondisi tempat tumbuh tutupan tajuk tertutup ditemukan sebanyak 13 jenis dan pada kedua tipe kondisi tempat tumbuh memiliki 6 jenis jamur yang sama.

2. Tingkat keanekaragaman jenis jamur makroskopis di lokasi penelitian adalah rendah.

3. Jenis jamur makroskopis yang ditemukan terdapat 4 jenis jamur yang dapat di konsumsi yaitu Chantarellus sp, Agaricus sp, Meripilus sp dan Craterellus sp. Satu jenis yang berbahaya untuk di konsumsi yaitu Entolama sp dan 19 jenis lainnya belum diketahui pemanfaatannya.

\section{DAFTAR PUSTAKA}

$\begin{array}{rrr}\text { Dewantara I. } & \text { 2017. } & \text { (KHDTK) } \\ \text { Universitas } & \text { Tanjungpura. } \\ \text { Memperkuat } & \text { Kawasan Hutan } \\ \text { Dengan Tujuan Khusus (KHDTK) } & \text { Kus } \\ \text { sebagai } & \text { Pusat } & \text { Belajar Mitigasi }\end{array}$ 
Perubahan Iklim di Provinsi Kalimantan Barat melalui Perlindungan dan Pengelolaan Gambut Berbasis Masyarakat, Pontianak. Hlm 1-2.

Hasanuddin. 2014. Jenis Jamur Kayu Makroskopis Sebagai Media Pembelajaran Biologi (Studi di TNGL Blangjerango Kabupaten Gayo Lues). Jurnal Biotik 2:1-76.

Laessoe T, Lincoff G, editor. 2002. Mushroom. New York: Dorling Kindersley.

Parjimo dan Andoko A. 2007. Budi Daya Jamur. Jakarta: Agromedia Pustaka.

Priskila, Ekamawanti HA, Herawatiningsih R. 2018. Keanekaragaman Jenis Jamur

Makroskopis di Kawasan Hutan Sekunder Areal IUPHHK-HTI PT. Bhatara Alam
Lestari Kabupaten Mempawah. Jurnal Hutan Lestari 6 (3) : 569 - 582.

Odum EP.1993. Dasar - Dasar Ekologi. Yogyakarta: Gajah Mada Univ. Press.

Setiorini JI, Astiani D, Ekamawanti HA. 2018. Keanekaragaman Jenis Jamur Makroskopis dan Karakter Tempat Tumbuhnya Pada Hutan Rawa Gambut Sekunder Di Desa Kuala Dua Kabupaten Kubu Raya Kalimantan Barat. Jurnal Hutan Lestari 6 (1) : 158 - 164.

Wahyudi AE, Linda R, Khotimah S. 2012. Inventarisasi Jamur Makroskopis Di Hutan Rawa Gambut Desa Teluk Bankung Kecamatan Sungai Ambawang Kabupaten Kubu Raya. Protobiont 1:8-11. 